\title{
Imago Sylvae. Strumenti di attraversamento e rappresentazione dello spazio selvatico
}

\author{
Vincenzo Moschetti
}

Abstract

L'avanzata delle selve, dimostrata dai dati statistici di natura nazionale e sovranazionale, ha aperto il campo della ricerca alla presenza di una natura incontrollata dove la paura, il Pan di Hillman," spalanca la porta su questa realtà" [Hillman 1977, p. 75]. II selvaggio è animato, è corpo vivo, che in qualità di anima mundi "indica le possibilità di animazione offerte da ciascun evento per come è, il suo presentarsi sensuoso come volto che rivela la propria immagine interiore [...] non solo animali e piante infusi di anima, come nella visione dei romantici, ma l'anima data con tutte le cose" [Hillman 2002, p. 130]. Ognuna di queste realtà si costruisce tra immagine (fantastico) e concretezza, attira e respinge, indaga e produce nella dimensione della rappresentazione e del progetto un organismo di eventi. Se la selva è quindi composta da un insieme complesso di 'fatti' e di spazi, la domanda da porre è come questi si raffigurano? Quali sono le strategie per riconoscere segni e tracce tali da produrre mappe per l'attraversamento?

II testo ha lo scopo di individuare gli elementi della selva ancorandoli a un mondo della rappresentazione e del progetto secondo una nuova tassonomia, in modo da indicare metodi che rendano il selvatico riconoscibile. La domanda a cui trovare risposta si compone attraverso passaggi che insieme possono dare un'immagine di quello che è lo spazio selvaggio inteso quale informe, nel senso batailliano del termine, e che rovescia (o aggiorna) le intersezioni consuete tra 'forma' e 'contenuto' mostrando le strutture di un possibile attraversamento per mezzo del progetto.

Parole chiave

indeterminato, informe, spazio della selva, sylva, wildness.

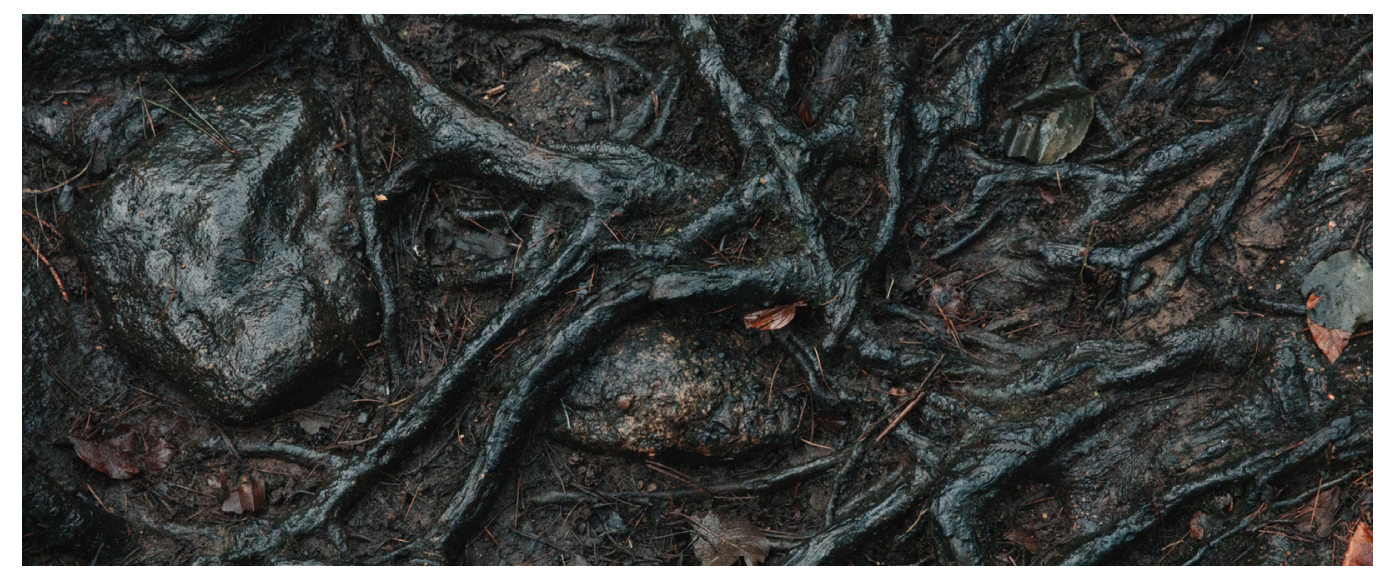




\title{
Introduzione alla selva e all'informe
}

\author{
"L'informe qualificherebbe dunque un certo potere \\ che hanno le forme stesse di deformarsi sempre, \\ di passare improvvisamente dal somigliante al dissomigliante", scrive Didi-Huberman; \\ l'informe è dunque completamente ripiegato sull'idea di deformazione
}

[Bois, Krauss 2003, p. 7I]

L'individuazione di una nuova urgenza sul riconoscimento dell'imago sylvae, nella doppia verità di immaginario e concretezza, scaturisce dall'avanzata di masse vegetali in forma di boschi e foreste, ma non esclusivamente, che i dati statistici nel solo territorio italiano indicano con una presenza superiore al 30\% rispetto alla superficie nazionale sviluppatasi a partire dal secondo Dopoguerra con un accumulo evidente proprio negli ultimi trent'anni [Agnoletto 20 I8]. II ritorno alla selvatichezza è pertanto figlio di "fluttuazioni disordinate che alterano l'equilibrio teorico" [Paci 2002, p.14], mostrando una necessità scientifica e operativa che possa intervenire negli ambiti del progetto d'architettura seguendo un processo di strumenti e riconoscimenti del sistema selvatico al fine di poterlo 'attraversare'. L'analisi, quindi, indaga un'immagine dinamica e concreta, ma allo stesso modo astratta, traducibile in temi e comportamenti dell'immaginario che si riversano tanto nella selva dantesca quanto nella wilderness americana. Da un lato si collocano le tracce lasciate dalla letteratura e dall'arte, dall'altro gli studi scientifici che a partire dalle premesse "ambientali" traducono l'esistenza di un mondo altro: quello della selva.

Beginning after the end è il titolo scelto da Morton in Dark Ecology, intravedendo per mezzo di una nuova ecologia percorsi e pensieri ora sotto la lente di questo testo. Essere dentro, nella selva,"in virtù del suo indicare una multitudo arborum diffusa et inculta" [Gentili, Giardini 2020, p. 84], conduce entro parametri organizzativi e spaziali del tutto nuovi, sconosciuti, proponendo un attraversamento senza un programma apparente. L'ambiguità dell'immagine selvatica determina "un magma di 'zone' nelle quali è facile perdersi ma è anche un 'ambiente' attraversabile disegnando linee di incursione. Per abitare la selva serve aumentare la capacità di riconoscimento, definire le modalità di convivenza, in pratica serve sancire una 'nuova alleanza"' [Marini 2020, p. I I]. In questo senso la mise en scène prefigurata dalla Commedia di Dante, a partire proprio dal Primo Canto, sembra fornire al campo della sperimentazione

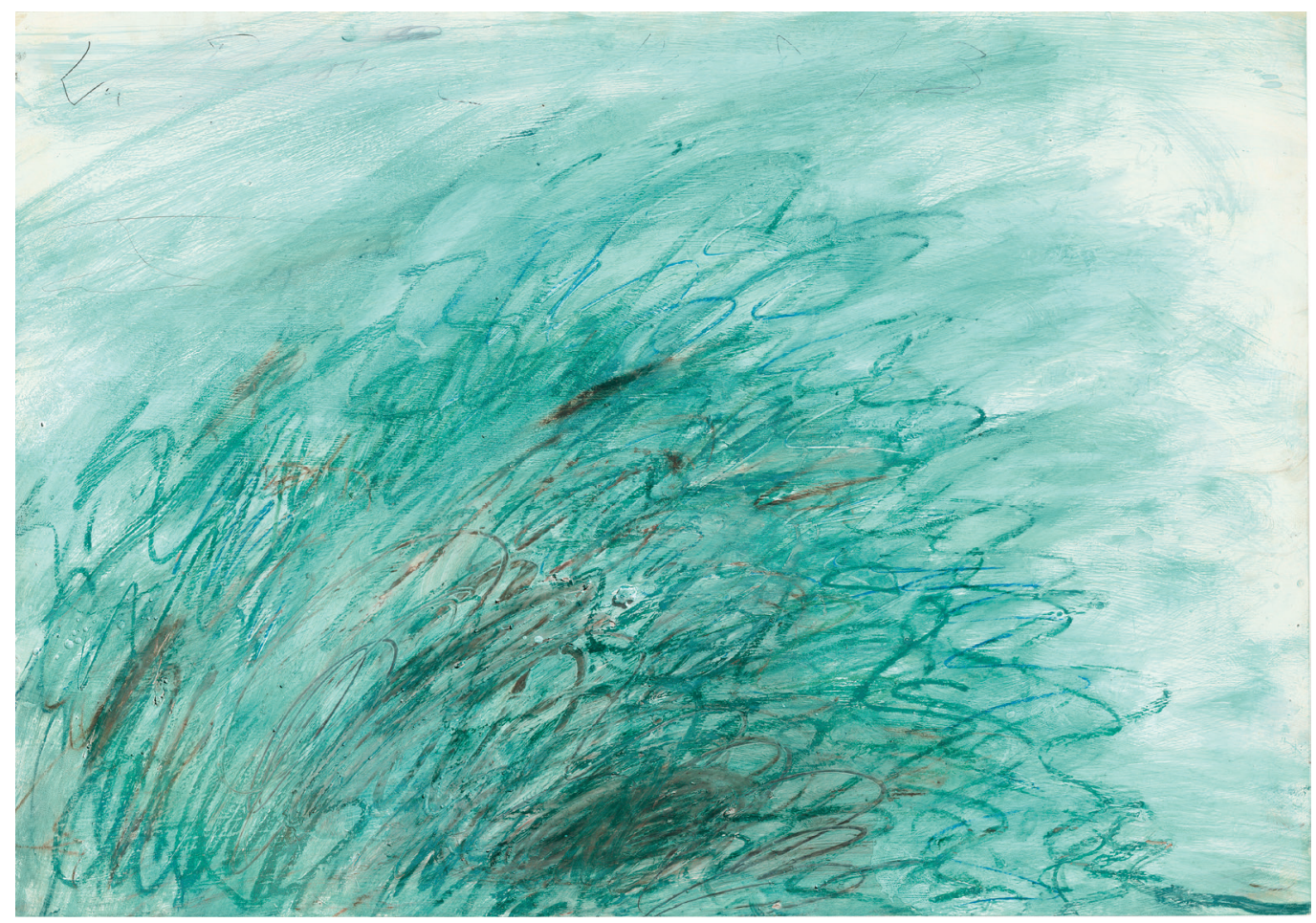


in atto un valore contemporaneo sostenuto dagli studi di Mancuso [I] dove, al contrario delle premesse medioevali [2], questo "essere in vita" da parte del selvatico è la prova di un nuovo sistema costruito per parole e immagini da Agamben così come da Morton in ambito filosofico, da Hillman in quello psicologico, oppure da Bois con Krauss in quello artistico, discutendo l'esistenza di "un ordine che esclude la legge" [Cacciari 1984] che ora cerca di definire incursioni nelle tematiche del progetto. Le pieghe messe in campo sono alimentate da microstorie che tentano di descrivere lo spazio e gli effetti, di strutturare un luogo dalla dimensione oscura cercando di attribuirne un senso che ricade, come manifestato da Bois e Krauss, nella nozione di 'informe', suggerendo quindi la traccia principale sulla quale ancorare il tema della selva e costruendo difatti l'analisi teorica proposta.

"In questa operazione di slittamento si potrebbe vedere una versione di quello che Bataille chiama 'informe'. Si tratta di un'operazione' (cioè né un tema, né una sostanza, né un concetto) e perché in quanto tale partecipa a un generale movimento del pensiero di Bataille, che egli amava chiamare 'scatologia' o 'eterologia'. Si tratta di reperire, a partire dall'informe', un certo numero di operazioni che prendono in contropiede il modernismo e di farlo senza opporsi alle sue certezze formali, con i mezzi delle più rassicuranti e ingenue certezze del senso. Al contrario, queste operazioni si distaccano dal modernismo insultando l'opposizione di forma e contenuto - essa stessa formale, derivante com'è da una logica binaria - dichiarandola nulla, e non valida" [Bois, Krauss 2003, pp. 3, 4].

Le condizioni proposte dagli autori a sostegno della mostra L'informe: mode d'emploi, ospitata al Centre Pompidou di Parigi nell'estate del 1996, indicano l'individuazione di categorie operazionali che motivano l'informe e che possono in questo senso agire come struttura teorica per comprendere gli elementi, ma soprattutto i "movimenti" del selvatico (fig. I). Così la presenza di animali e piante, di pollini e batteri, tiene in vita questo ordine "impossibile" imponendo un armamentario di azioni, cause ed effetti di un disordine tuttavia tassonomico basato su operazioni, come quelle dell'informe appunto, che aggiornano l'apparato, rispondendo, attraverso il nome di pulsazione ed entropia, alle necessità teoricoanalitiche sull'avanzata delle selve e sul loro spazio. In questo senso si intende "mettere l'informe in atto, non soltanto reperire un certo numero di traiettorie, o di slittamenti, ma per quanto poco metterli all'opera" [Bois, Krauss 2003, p. 8].

Definire quindi un discorso per operazioni proprio partendo dalla critica sia letteraria che artistica, permette di costruire incursioni e metodi da poter rendere riconoscibili nella disciplina del progetto. II metodo di analisi, dunque, attraversa due piste principali: quella dell'arte e quella dell'architettura. La prima affronta l'indeterminato secondo contesti assodati da Bois e Krauss restituiti nel catalogo, stabilendo difatti 'modi d'uso', categorie operatorie; l'architettura, al contrario, si manifesta sotto tracce, dispositivi, ovvero linee di tensione o spostamenti da ricostruire e individuare. Entrambi i processi, tuttavia, avanzano per programmi che stabilisco metodologie per definire i campi mediante i quali la selva si mostra, dove l'oscurità (orizzontalità) e l'aperto (pulsazione) si affiancano all'entropia di un corpo interno interessato da spostamenti a doppie velocità (animali e vegetali) che compongono l'affresco di un basso materialismo che è possibile chiamare 'selva'.

\section{Presenze animali, tracce vegetali: l'interno}

Le colature provenienti dalla costruzione critica discussa da Mandel'štam, ripresa da Rizzi sulla possibile definizione della parola 'forma' [3], intesa come lemma di un Dizionario destinato principalmente ma non esclusivamente all'architettura, mostra come la Commedia di Dante esprima in forma scritta una primordiale teoria del dripping [Rizzi 2016] attraverso l'uso di metafore zoologiche. II processo di colare o gocciolare vernice, spesso utilizzando una tela o un supporto steso sul pavimento (orizzontalità), descrive il principio di rappresentazione in grado di sostenere le tracce di un mondo interno appartenente alla selva. Se la domanda posta in partenza è quella di quali siano gli strumenti e le figure destinate a rappresentare il selvatico, sulla scia dell'informe il dripping emerge come sostanziale tecnica di costruzione dell'immagine di un organismo che si avvera per mondi, strati e tensioni 
Fig. 2. Jackson Pollock (1912-1956), Profondo cinque braccia (Full Fathom Five), 1947. New York, Museum of Moder Art (MoMA) Olio tel (MoMA). Olio su de con chiodi, puntin chiave, monete, sigarette $129.2 \times 76.5$. Dono 129.2 × 76.5. Dono di Peggy Guggenheim. Inv. n. 186.1952. () 2021. Digit image, The Museum of Modern Art, New York/ Scala, Firenze. sistemiche dove il rimando è spazio. Pollock, ad esempio, lavora alle sue composizioni per tempi molto lunghi facendo in modo che pensieri e vernici si sommino a tracce provenienti da "tempeste", del resto lo stesso titolo destinato al Full Fathom Five (I 947) proviene da La Tempesta [4] di William Shakespeare.

I nodi del dripping (fig. 2) sono indirizzati a chiarire quelle questioni su ciò che contraddistingue il corpo della selva, costituita dunque da un insieme di organi e organismi, animali, piante e batteri, da un sistema che fino a ora non ha trovato posto in una definizione certa, sfuggita al controllo, e che - recuperando le teorie dell'informe appunto - ha luogo nello sprofondamento entropico, inteso come accumulo o spreco irrecuperabile.

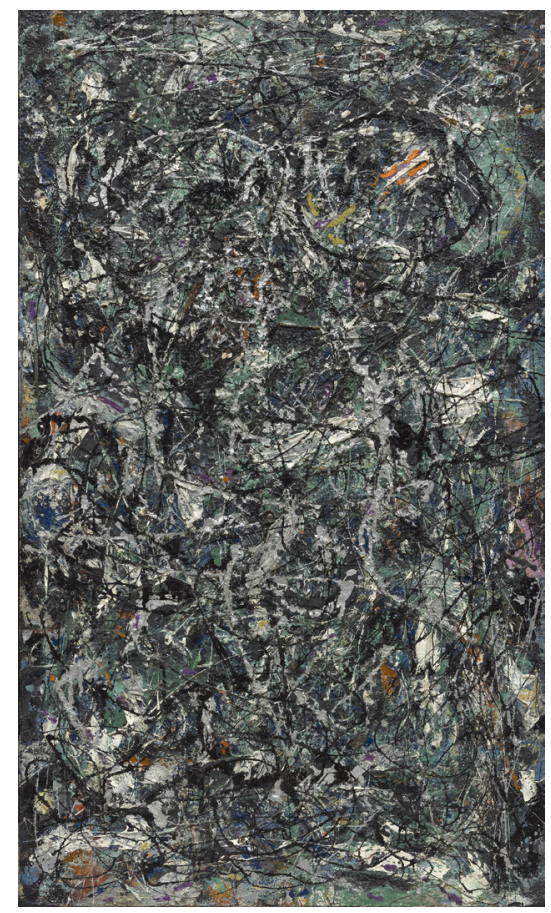

“La soluzione a cui pervenne Pollock, all'inizio del 1947, tornando in qualche modo alla logica del loft di Union Square, fu di spazzare il piano orizzontale della scrittura dalla tavola che ne faceva un sostituto della 'cultura', per riversarlo - come un secchio di spazzatura - sul pavimento della rivolta anticulturale di Siqueiros. II pavimento è ciò che sembra proporre il lavoro di Pollock, essendo al di sotto della cultura, sfugge all'asse del corpo, e perciò anche della forma. Questo afflusso eterogeneo di rifiuti che Pollock versa sulla tela nel corso della sua esecuzione testimonia non solo del 'significato interno' dell'orizzontalità dell'opera ma anche della 'bassezza' di questa condizione" [Bois, Krauss 2003, p. 92].

Le immagini del dripping parlano di piste che trovano riscontro nel tema della selva; se l'oscurità mina il riconoscimento delle diverse parti rendendole sconosciute (ma non invisibili), la tecnica di Pollock le mette in mostra attraverso colori e spessori. La riduzione di movimenti entropici nel palinsesto architettonico, sulla scorta di mappe anticipate da Dante ('inventore' del dripping) e rappresentate da Pollock, trova terreno fertile nelle operazioni dell'incontro' di Libeskind, uno spazio, "a document of the unpredictable and an acknowledgment of the uncertain. In this, it reflects the nature of architecture itself. The spirit of architecture wanders where it will"' [Libeskind 200 I, p. I7]. II progetto Micromegas: The Architecture of Endspace (1979) (fig. 3) ha avuto il suo innesco attraverso una serie di undici disegni a matita quale base per alcune stampe successive. "Architectural drawings [scrive Libeskind] have in modern times assumed the identity of signs; they have become the fixed and silent accomplices in the overwhelming endeavor of building and construction [...] they have appeared as either self-effacing materials or as pure formulations cut off from every external reference" [Libeskind 200I, p. 84]. 
Fig. 3. Daniel Libeskind (1946), Progetto per Micromega. Sezioni temporal 1979 New York Museum of Modern Art (MoMA). Silkscreen on paper, 26 $\times 36$ I/8' $(66 \times 91.8 \mathrm{~cm})$. Robert K. and Barbara J. Straus Family Foundation Inc. 271.1999 (C) 2021.

Digital image, The Museum of Modern Art New York/Scala, Firenze.

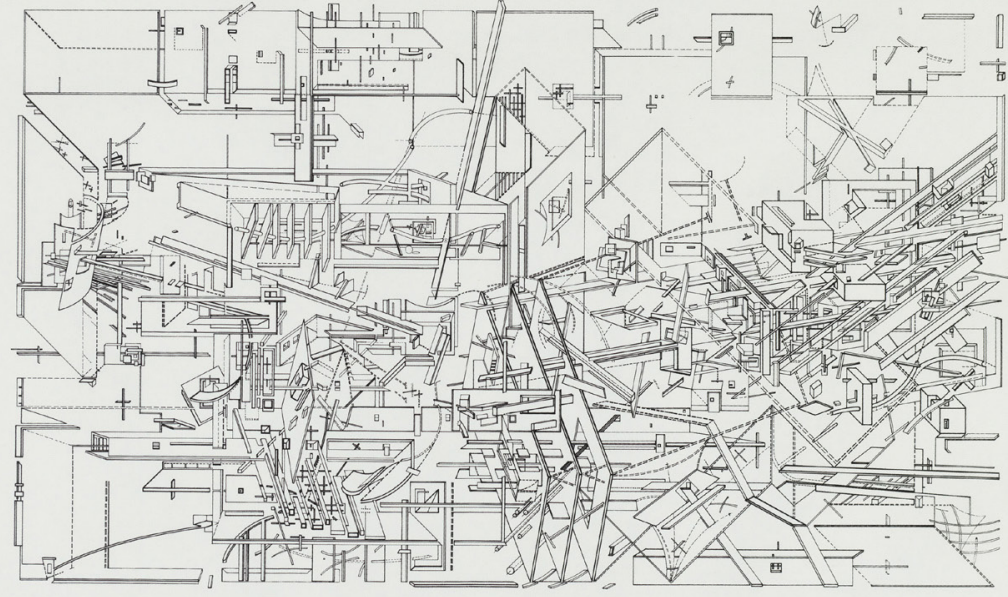

$2 / \%$

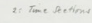

Gli strumenti forniti da Libeskind, tramite il disegno, associano alla selva il compito di dispositivo, provvista dunque di linee di tensione tali da rendere i Micromegas dei concreti campi interpretativi, nei quali l'azione espressa da Agamben [2006] trova una collocazione rappresentabile e in cui è possibile riconoscere una lettura e restituzione di uno spazio che si rivolge all'informe. Micromegas non propone condizioni al contorno ma entra nel selvatico riflettendo su un metodo che investe la rappresentazione "selvaggia" parlando di progetto architettonico e di condizioni dello spazio. I disegni sovvertono l'assioma classico elaborato rispetto a una teoria dell'ordine [Bertagna $20 \mathrm{l}$ l], costruendo un sistema formale "as riddles-unknown instruments for which usage is yet to be found [...] an instrument capable of revealing at a stroke new areas of the 'real"' [Libeskind 200 I, p. 84]. II selvatico trova spazio in questa nuova realtà sconosciuta, o dimenticata, dove "è la traccia che, separando mentre segna, costituisce il motore dell'eterogeneità, l'istigatore della différance" [Bois, Krauss 2003, p. I 62]. I vari livelli del selvatico possono quindi essere assunti trasversalmente come estensione di una realtà sia immaginaria che concreta, rivelando "a structure whose manifestation is only mediated by symbolism" [Libeskind 200 I, p. 84]. "Qui, dunque, non si tratta di una differenza costituita ma, prima di ogni determinazione di contenuto, del movimento 'puro' che produce la differenza. 'La traccia (pura) è la differenza'. Essa non dipende da alcuna pienezza sensibile, udibile o visibile, fonica o grafica. Al contrario ne è la coincidenza" [Derrida 1969, p. 70].

La messa in scena in una realtà differente nella quale il selvatico trova posto mostra - nelle operazioni di Libeskind e non solo - l'assenza di un controllo ma soprattutto l'inesistenza - la previsione di condizioni definitive, "an exchange between abstract ciphers exhausted in their own objectivity and hardened in fixed signs; and concrete contingencies responsive to the permanent solicitations of a spontaneous appeal"' [Libeskind 200I, p. 87]. Gli elementi che compongono il Little Universe si delineano dal rilevamento del terreno trasponendo la raffigurazione di tracce e movimenti in operazioni "whose nucleus is the conflict between voluntary and the involuntary" [Libeskind 200I, p. 87] non sempre coincidente comunque con quello di ordine e disordine.

I disegni per il Forest Kindergarten (20 I 8) (fig. 4) di Ishigami, fondando ulteriormente la teoria, traspongono tracce di un destino che appunto Bataille aveva prefigurato nella voce dedicata al primitivismo e che nelle rappresentazioni per l'asilo a Shandong, in Cina, si presentano 
Fig. 4. Junya Ishigami, Forest Kindergarten, 2018, (Ishigami, Junya, Freeing Architecture, LIXIL Publishing - Fondation Cartier pour l'art contemporain, Tokyo Paris 2018, pp. 146-147) (c) Junya Ishigami.

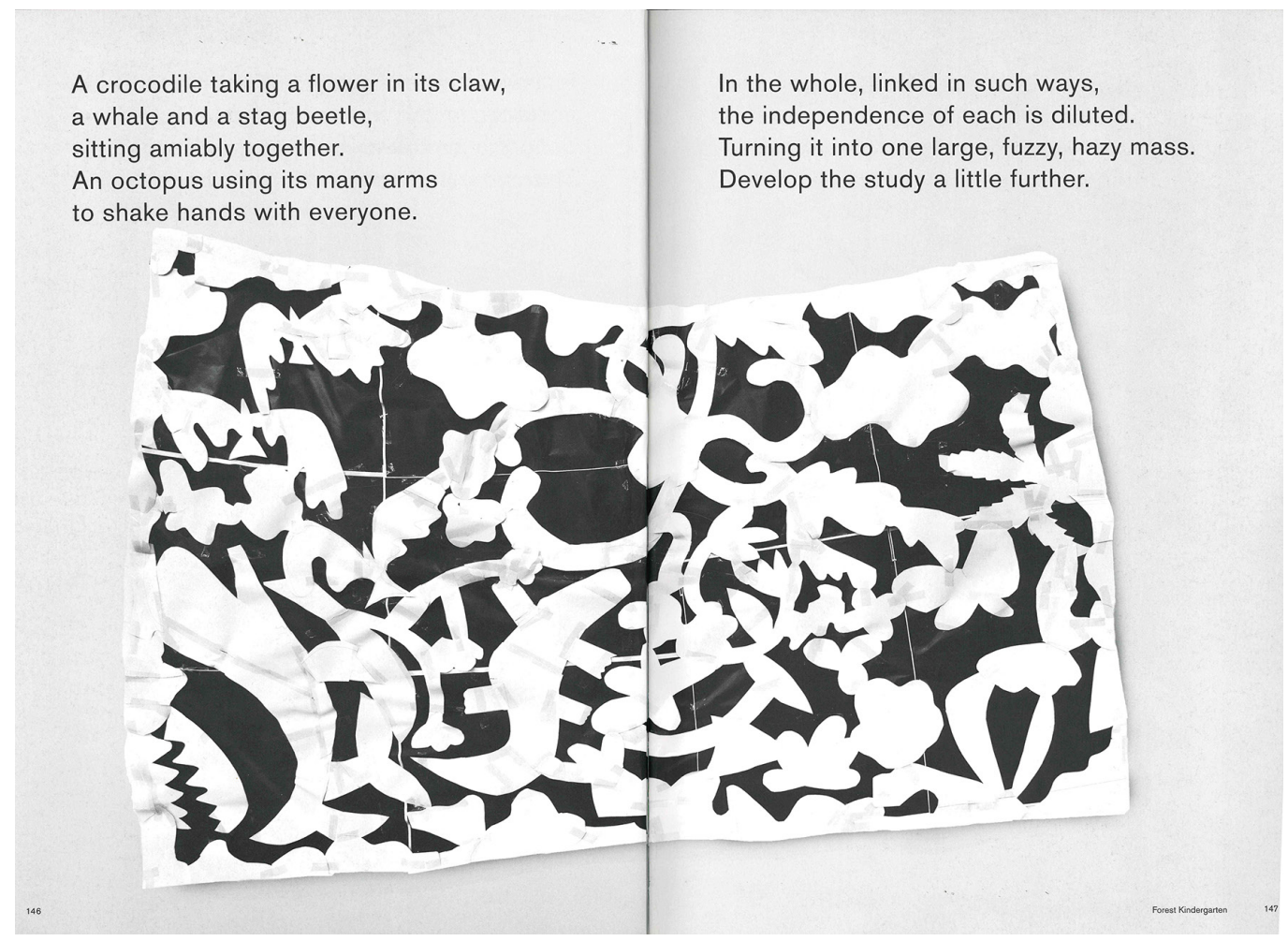

come possibili piste selvatiche. I bambini percorrono spazi di una foresta quasi incantata, producono mappe e infittiscono segni, sommandosi a quelli della vegetazione e a quelli di animali viventi e riprodotti nel gioco architettonico. Astrazione e concretezza, così come immaginazione e realtà, guidano i percorsi senza costringere le interazioni, permettendo a grandi animali di definire spazi e incoraggiare spostamenti e 'colature'. Ishigami opera in un mondo dove divergono "subjectivity and objectivity, immanence and transcendence, concrete and abstract" [Ishigami 20 I8, p. 145] producendo una sequenza di mappe che intersecano i campi di percorrenza dei bambini con quelli degli adulti, fino a mescolare i percorsi possibili in un doppio circuito, verticale e orizzontale, all'interno di una massa grande, sfocata e nebulosa. "Adult-scale, child scale, interior, exterior, play equipment, landscape, plants, structures, brightness, darkness, quiet, noise, architecture extends amid all kinds of things merging into each other. [...] Ponder them at length in different ways, envisioning spaces within the lines. Like finding clearings in the jungle" [Ishigami 2018, pp. |57-|6I].

\section{Epilogo}

"Le piante coincidono con le forme che inventano: per loro tutte le forme sono declinazioni dell'essere, e non del fare o dell'agire. Creare una forma significa attraversarla, percorrerla con tutto il proprio essere, allo stesso modo in cui si percorrono le età o le tappe dell'esistenza. All'astrazione della creazione e della tecnica - capaci di trasformare le forme solo a patto di escludere l'artista e il produttore dal processo di trasformazione - la pianta oppone l'immediatezza della metamorfosi: generare significa sempre trasformarsi'" [Coccia 2019, p. 30]. Seguendo una voce apparsa nel n. 7 del Dictionnaire Critique di Bataille, l'informe rielabora la selva e il selvatico, proponendo una condizione tanto al presente quanto al futuro dove ci sarà sempre più spazio inselvatichito da attraversare. Le immagini di Ishigami (fig. 5) seguono una possibile genealogia anticipata da Libeskind, dove la trasformazione individuata da Coccia esprime le modificazioni di senso entropico delle parole 'colate' di Dante secondo 
Mandel'štam, fino alla tecnica dripping di Pollock, proponendo metodi di lettura di un sistema informe nel quale la selva trova posto. "Once again this duality (like that of realism-formalism) appears as an unsurpassable condition pointing to a dynamic ground, which testifies to an experience that receives only as much as it is capable of giving, draws only that which allows itself to be drawn into" [Libeskind 200 I, p. 87].

La dinamicità del terreno selvatico, che incrocia più tracce sprovviste di ordine, propone quindi una revisione delle nozioni disciplinari in campo architettonico, individuando nuove modalità d'uso e di 'attraversamento' dove gli sviluppi progettuali discussi rappresentano il diagramma di "una figura non esatta, che offre uno schema generale, improntata a raccontare la forma e le relazioni tra le parti, una forma non precisa né definitiva, che può subire modifiche, ma che riporta i risultati di un processo e le variazioni che lo caratterizzano" [Marini 2010, p. 90]. Questa figura, stando alla teoria percorsa, è quella dell'imago sylvae, dell'informe' nel quale il selvatico si ancora introducendo scenari operativi e rappresentabili per conto di mappe, mostrando le strutture di un possibile attraversamento per mezzo del progetto.

Questi disegni anticipano un'immagine della selva che non solo si rivolge al vegetale o all'animale (fig. 6) ma che ragiona anche sui tessuti di quelle parti di città che hanno perduto il controllo e i caratteri di ordine. Le mappe divengono materiale speculativo per interpretare un sistema ambiguo disegnando come visto eventuali linee di incursione; ovvero un apparato di strategie tali da aumentare le modalità di convivenza, figurando in questo senso una nuova e possibile 'alleanza' tra biologico (selva) e artefatto (progetto).

Fig. 5. Junya Ishigami, Forest Kindergarten, 2018, (Ishigami, Junya, Freeing Architecture, LIXIL Publishing - Fondation Cartier pour l'art contemporain, Tokyo Paris 2018, pp. |60-161) (C) Junya Ishigami.

Fig. 6 Gaston Phoebus, Libro della caccia, (dettaglio) 19.1 × 15.3 $\mathrm{cm}, 1405-1410, \mathrm{RCIN}$ 912431, Ms. fr. 616 (c) Paris, Bibliothèque Nationale de France.
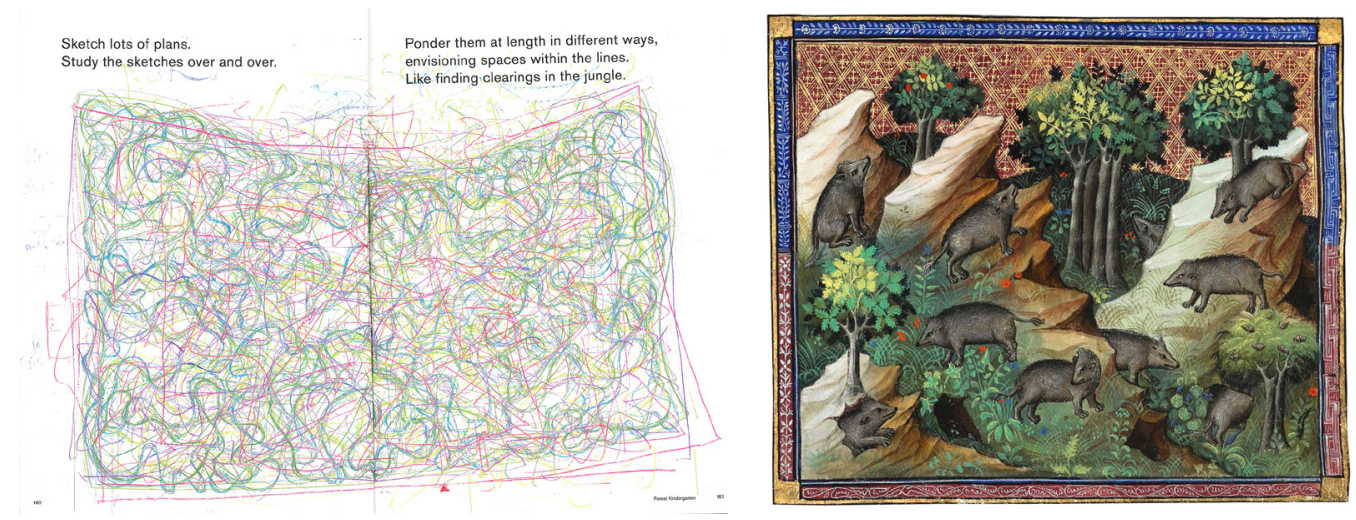

\section{Credit}

Parte dei risultati qui presentati sono l'esito della ricerca in corso di svolgimento presso l'Università luav di Venezia nell'ambito del PRIN "SYLVA. Ripensare la «selva». Verso una nuova alleanza tra biologico e artefatto, natura e società, selvatichezza e umanità", Unità di Ricerca luav di Venezia (responsabile scientifico: prof.ssa Sara Marini).

\section{Note}

[I] "La flessibilità del corpo delle piante è imparagonabile:" plasticità fenotipica" è la dizione tecnica con la quale si descrive questa abilità. Riducono la loro taglia, si ispessiscono, si assottigliano, si avvolgono, curvano, salgono, strisciano, modificano la forma del loro corpo, interrompono la propria crescita, fanno tutto ciò che è necessario perché il loro equilibrio con l'ambiente sia il più stabile possibile. [...] Una specie di paradosso per degli organismi viventi che noi percepiamo come immobili e stanziali e che, al contrario, sono in grado di valicare barriere e colonizzare territori lontani e inospitali, dietro la spinta irresistibile della vita a espandere la propria presenza" [Mancuso 2019, pp. 108-1 I7].

[2] In questo senso le immagini religiose medievali pur rivolgendosi al 'naturale' non trovano riscontro con l'universo delle selve; i temi emessi patristicamente vengono posizionati secondo un diagramma privo di vie di fuga dove le iconografie risultano essere progetti finiti, da osservare, allinterno delle quali la foresta si presenta unicamente in forma simbolica dove "un esempio sono i paesaggi giotteschi, vere e proprie architetture in cui i boschi sono raffigurati con pochi alberelli stilizzati" [Paci 2002, p. 32]

[3] "in Dante non c'è una forma unica, ma una pluralità di forme. Le quali colano per spremitura una sull'altra" [in Rizzi 20 I6, p. 249].

[4] "Full fathom five thy father lies;/ Of his bones are coral made;/ Those are pearls that were his eyes:/ Nothing of him that doth fade/ But doth suffer a sea-change/ Into something rich and strange/ Sea-nymphs hourly ring his knell/ Hark! Now I hear them - Ding-dong, bell' [Shakespeare, The Tempest, Act. I, Sc. II, ca. I6|0-I I]. 


\section{Riferimenti bibliografici}

Agamben G. (2006). Che cos'è un dispositivo?. Milano: Nottetempo.

Agnoletto M. (20|8). Storia del bosco. Il paesaggio forestale italiano. Bari: Laterza.

Bataille G. (1930). Les écarts de la nature. In Documents, n. 2, pp. 79-83.

Bataille G. (1974). Documents. Bari: Dedalo.

Bertagna A. (20 I I). Il controllo dellindeterminato: Potëmkin villages e altri nonluoghi. Macerata: Quodlibet.

Bois Y.-A., Krauss R. (2003). L'informe: istruzioni per l'uso. Milano: Mondadori.

Cacciari M. (1984). Un ordine che esclude la legge. In Casabella, n. 498-499, pp. I4, I5.

Cixous H. (1976). The Laugh of Medusa (translated by K. Cohen and P. Cohen). In Signs, vol. I, n. 4, pp. 875-893.

Coccia E. (2019). La vita delle piante. Metafisica delle mescolanze. Bologna: il Mulino.

Derrida J. (1969). Della grammatologia. Milano: Jaca Books.

Gentili D., Giardini, F. (2020). Selva e stato di natura: variazioni cinestesiche per il contemporaneo/ Sylva and State of Nature: Kinesthetic Variations for the Contemporary. In Vesper. Rivista di architettura, arti e teoria, n. 3, pp. 76-95.

Hillman J. (1977). Saggio su Pan (trad. it. A. Giuliani). Milano: Adelphi. [Prima ed. An Essay on Pan, in Pan and the Nightmare (con W. H. Roscher), Spring Publications, New York-Zürich 1972, pp. 3-65].

Hillman J. (2002). L'anima del mondo e il pensiero del cuore (trad. it. A. Bottini). Milano: Adelphi. [Prima ed. Anima Mundi:The Return of the Soul to the World. In Spring, 1982, pp. 7|-93].

Hillman J. (2016). Presenze animali (trad. it. di A. Serra e D.Verzoni). Milano: Adelphi. [Prima ed. The Animal Kingdom in the Human Dream. In Eranos Jahrbuch, n. 5I, 1982, pp. 279-334]

Ishigami J. (20I8). Freeing Architecture. Fondation Cartier pour l'art contemporain. Paris: LIXIL Publishing.

Libeskind D. (1997). Radix-Matrix. München-New York: Prestel.

Libeskind D. (200I). The Space of Encounter. London:Thames \& Hudson Ltd.

Mancuso S. (2019). La nazione delle piante. Bari-Roma: Laterza.

Mandel'štam O. (2003). Conversazioni su Dante (a cura di R. Faccani). Genova: II Melangolo.

Marini S. (20 I0). Nuove Terre. Architetture e paesaggi dello scarto. Macerata: Quodlibet.

Marini S. (2020). Nella selva/ Wildness. In Vesper. Rivista di architettura, arti e teoria, n. 3, pp. I0- I7.

Marini S., Bertagna A. (20I I) (Eds.). The Landscape of Waste. Milano: Skira.

Morton T. (20 I 6). Dark Ecology. For a Logic of Future Coexistence. New York: Columbia University Press.

Paci M. (2002). L'uomo e la foresta. Milano: Meltemi.

Rizzi R. (20 16). Forma. In S. Marini, G. Corbellini (a cura di). Recycled Theory: Dizionario illustrato/ Illustrated Dictionary. Macerata: Quodlibet, pp. 248-249.

\section{Autore}

Vincenzo Moschetti, Università IUAV di Venezia, vmoschetti@iuav.it

Per citare questo capitolo: MoschettiVincenzo (202I). Imago Sylvae. Strumenti di attraversamento e rappresentazione dello spazio selvatico/Imago Sylvae. Instruments for navigating and representing the wilderness. In Arena A.. Arena M. Mediati D. Raffa P. (a cura di). Connettere. Un disegno per annodare e tessere Linguagoi Distanze Tecnologie Atti del $42^{\circ}$ Convegno Internazionale dei Docenti delle Discipline della Rappresentazione/Connecting Drawing for weaving relationship. Languages Distances Technologies. Proceedings of the $42^{\text {th }}$ International Conference of Representation Disciplines Teachers. Milano: FrancoAngeli. $909-924$ 


\title{
Imago Sylvae. Instruments for Navigating and Representing the Wilderness
}

\author{
Vincenzo Moschetti
}

Abstract

The advance of forests, demonstrated by both national and supranational statistical data, has opened the field of research to the presence of a wild nature in which fear, Hillman's Pan, "thrusts open the door to this reality" [Hillman 1977, p. 75]. The wilderness is animated, it is a living body which, in its quality as anima mundi, "indicates the animating possibilities offered by each event as it is, its sensuous manner of presenting itself as a face that reveals its own interior image [...] not only soul-infused animals and plants, as in the vision of the Romantics, but the spirit which lives in all things" [Hillman 2002, p. 1301. Each of these actualities is constructed between image (the fantastic) and concreteness, it attracts and repels, inquires, and produces, in the dimension of representation and of the project, an organism of events. If the forest is composed by complex set of 'facts' and spaces, the question we must ask ourselves is: how are they represented? What are the strategies for recognising signs and traces capable of producing maps to help us traverse them?

The purpose of the text is to identify the elements of the forest and to anchor them to the world of representation and of the project in accordance with a new taxonomy, so as to indicate methods that make the wilderness recognisable. The question for which we seek an answer is made up of passages which together can provide an image of what the wilderness is, understood as formless, in the sense given by Bataille to the term, and which capsizes (or updates) the usual intersections between 'form' and 'content', thus highlighting the structures of a possible crossing by way of the project.

Keywords

undetermined, formless, space of the forest, sylva, wilderness.

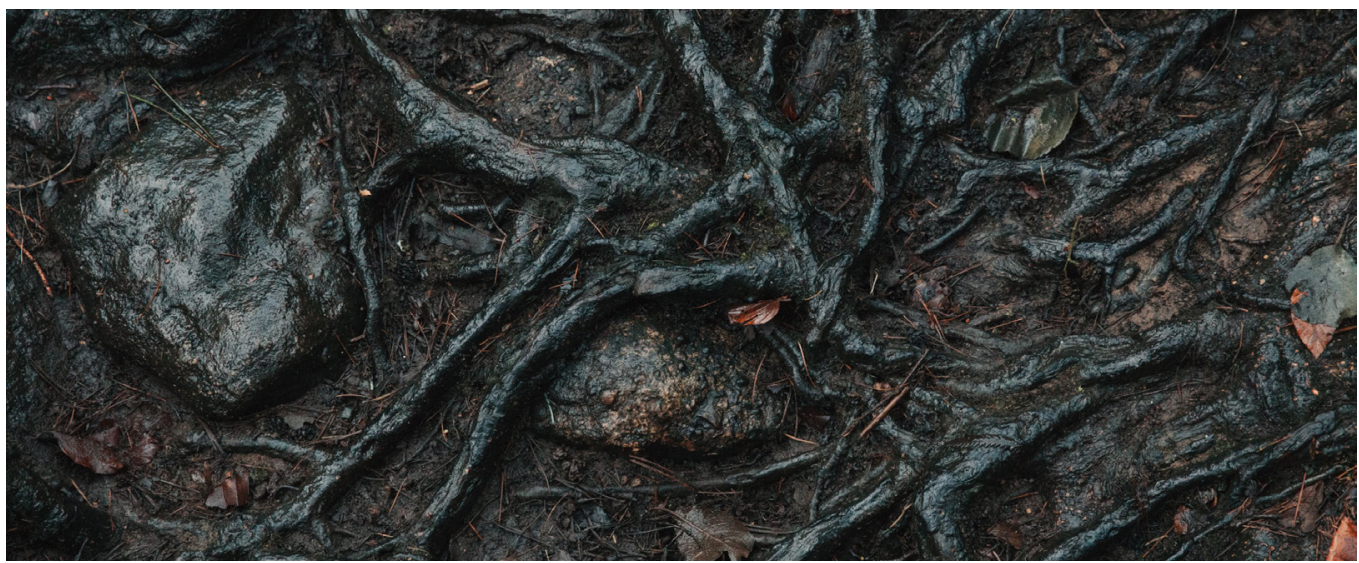




\section{Introduction to the Sylva and to the formless}

"The informe would thus specify a certain power
that forms have to deform themselves constantly,
to pass quickly from the like to the unlike,"
Didi-Huberman writes; and in so doing the informe
is thus neatly mapped onto the idea of deformation".

[Bois, Krauss 1997, p. 80]

The identification of a new urgency concerning the recognition of the imago sylvae, in terms of the double truth of the imaginary and of concreteness, is derived from the advance of vegetal masses in the form of woods and forests, but not exclusively, that statistical data for the Italian territory indicate as having a surface that is 30\% higher in relation to the national surface, as a result of a development which took place mostly from the second after-war period, showing an evident growth increase precisely during the past thirty years [Agnoletto 20I8]. The return to the wild thus originates in those "disorderly fluctuations that alter a theoretical balance" [Paci 2002, p. 14], demonstrating the need for a scientific and operative instrument that is capable of intervening in the field of architectural projects while following a process involving tools and recognition devices for the forest system, so as to be able to "traverse" it. The analysis therefore inquire into an image which is both dynamic and concrete, yet also abstract, that can be translated into themes and behaviours of the imaginary which refer back to Dante's forest as much as they do to the American wilderness. On the one hand we have the traces left behind by literature and art, and on the other the scientific studies which, based on "environmental" premises, translate the existence of an other different world: that of the forest.

Beginning after the end is the title chosen by Morton in Dark Ecology, in which he glimpses through the perspective of a new ecology, itineraries and thoughts that are also under scrutiny in this text. To be truly inside the forest, "by virtue of its denoting a multitudo arborum diffusa et inculta" [Gentili, Giardini 2020, p. 84], leads within completely new organisational and spatial parameters, thus proposing to undertake a crossing without any apparent programme. The ambiguous nature of the image of the forest determines "an agglomeration of 'zones' in which it is easy to get lost, but also an 'environment' that can be

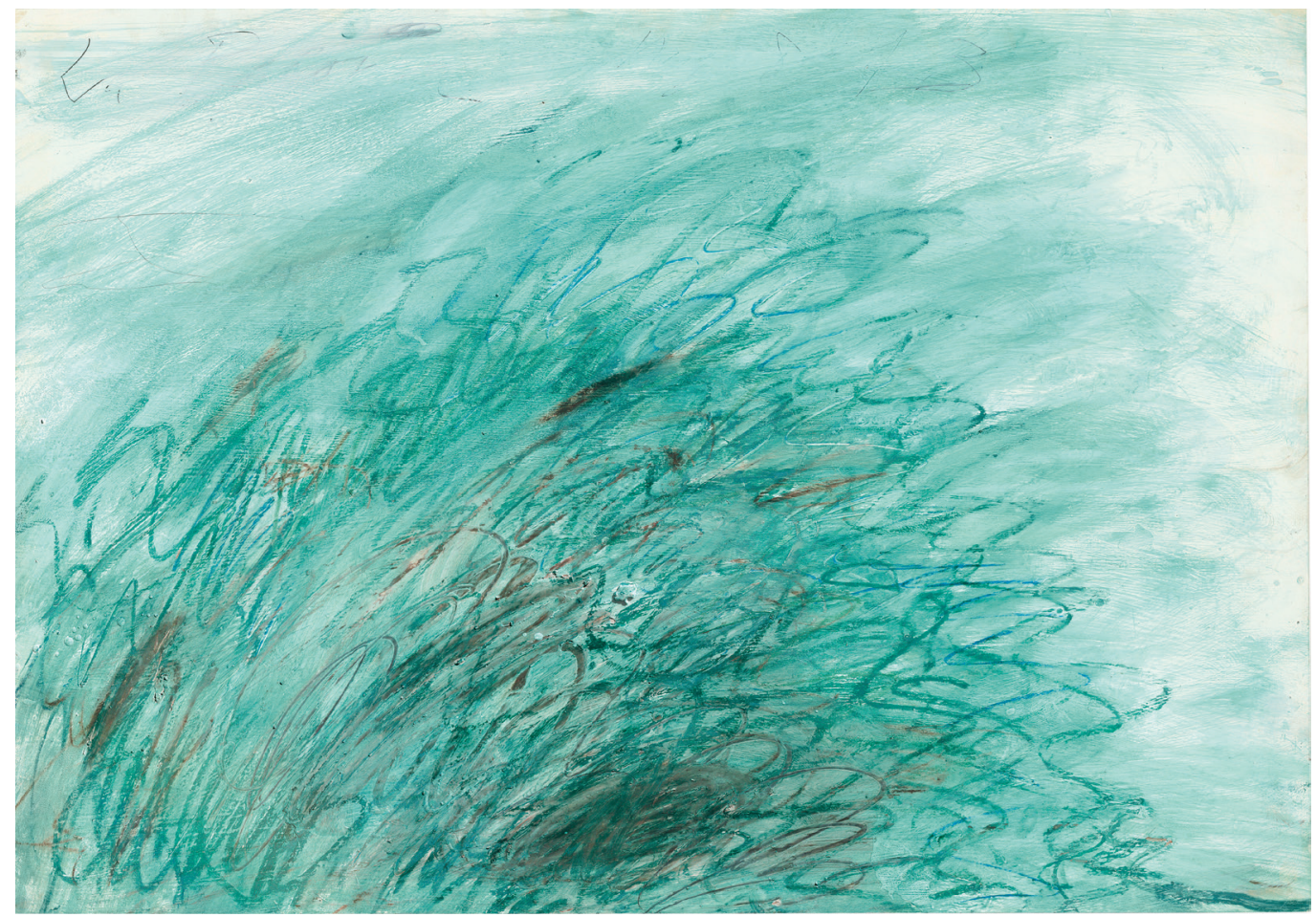


crossed by drawing lines of incursion. To inhabit the wildness means increasing the capacity for recognition, defining modes of coexistence; fundamentally, a 'new alliance' is called for" [Marini 2020, I5]. In this sense the mise en scène established by Dante in his Commedia from the very first Canto, seems to provide the current field of experimentation with a contemporary value that is supported by Mancuso's studies [I] in which, contrary to Mediaeval premises [2], this 'being alive' of the wilderness is the evidence for a new system that has been constructed in words and images by Agamben, by Morton in philosophical terms, as well as by Hillman in the realm of psychology, and by Bois and Krauss in the arts, bringing into discussion the existence of an "order that excludes the law" [Cacciari 1984] which is trying to carry out incursions into project-related themes. The folds encountered on field are fuelled by microstories that attempt to describe spaces and effects, to structure a dark place while seeking to attribute to it a meaning which falls back, as expressed by Bois and Krauss, on the notion of the 'formless', thus suggesting the main trace on which to anchor the theme of the forest, and in fact constructing the proposed theoretical analysis.

"In this operation of slippage we see a version of what Bataille calls the informe (formless). $[\ldots]$ it is an operation (which is to say, neither a theme, nor a substance, nor a concept) and that to this end it participates in the general movement of Bataille's thought which liked to call 'scatology' or 'heterology' [...] it is a matter instead of locating certain operations that brush modernism against the grain, and of doing so without countering modernism's formal certainties by means of the more reassuring and naive certainties of meaning. On the contrary, these operations split off from modernism, insulting the very opposition of form and content -which is itself formal, arising as it does from a binary logic- declaring it null and void" [Bois, Krauss 1997, pp. 15-16].

The conditions proposed by the authors in support of the exhibition L'informe: mode d'emploi, presented at the Centre Pompidou of Paris in the summer of 1996, indicate the identification of operational categories that motivate the formless and which can in this sense act as theoretical structure for understanding the elements, but especially the "movements" of the wild (fig. I). Thus, the presence of animals and plants, pollen and bacteria, keeps this "impossible" order alive and imposes an arsenal of actions, causes and effects from an albeit taxonomic disorder based on operations, such as that of the formless, precisely, which update the apparatus, responding under the name of pulsations and entropy, to the theoretical and analytic needs concerning the advance of forests and of their space. In this sense it is intended to "put the formless to work, not only to map certain trajectories, or slippages, but in some small way to 'perform' them" [Bois, Krauss 1997, pp. I8-2 I].

To determine a discourse for operations based precisely on criticism, both literary and artistic, allows us to build incursions and methods for recognition into project-related disciplines. The method of analysis, therefore, intersects two main pathways: those of art and of architecture. The first addresses the indeterminate in accordance to contexts ascertained by Bois and Krauss and presented in the catalogue, thus in fact establishing 'methods of usage', operating categories; architecture, on the contrary, is manifested in the form of traces or devices, in other words as lines of tension or as movements to be reconstructed and identified. Both processes, however, move forward through programmes that establish methodologies for defining the fields in which the forest makes itself apparent, where darkness (horizontality) and the open (pulsation) stand next to the entropy of an interior body that undergoes doublespeed changes of position (both animal and vegetal) that compose the picture of a low form of materialism that we can call 'forest'.

\section{Animal presences, vegetal traces: interior}

The 'drippings' derived from the critical construction discussed by Mandelstam, and retaken by Rizzi, on the possible definition of the word 'form' [3], understood as the lemma for a Dictionary that is mainly, yet not exclusively, devoted to architecture, show how Dante's Commedia expresses in writing a primordial theory of 'dripping' [Rizzi 20 I6] through the use of zoological metaphors. The process of dripping paint, often using a canvas or another surface placed on 
Fig. 2. Jackson Pollock (1912-1956), Full Fathom Five, 1947. New York, Museum of Modern Art (MoMA). Oil on canvas with nails, thumbtacks, buttons, keys, coins, cigarettes, matches, etc., cm. 129.2 $\times$ 76.5. Dono di Peggy Guggenheim. Inv. n. 186.1952. () 2021. Digita image, The Museum of Modern Art, New York Scala, Firenze. the floor (horizontality), describes the principle of representation that is capable of supporting the traces of an interior world which belongs to the forest. If the starting question regards the instruments and figures used for representing the wild, 'dripping' emerges as an essential technique in the construction of the image of an organism that is actualised by way of systemic worlds, layers and tensions which refer back to space. Pollock, for example, would work on his compositions for long periods of time, so that both thoughts and paint would sum up together with traces derived from "tempests". As a matter of fact, the title Full Fathom Five (1947) is taken from The Tempest [4], by William Shakespeare.

The cruxes of the 'dripping' (fig. 2) are aimed at clarifying question related to that which identifies and differentiates the body of the forest, constituted by an ensemble of organs and organisms, animals, plants and bacteria, by a system which to this day has not been defined entirely beyond doubt, which evades control and -returning to the theories on the formlesstakes place in the entropic sinking, understood as either growth, or as irrecoverable waste.

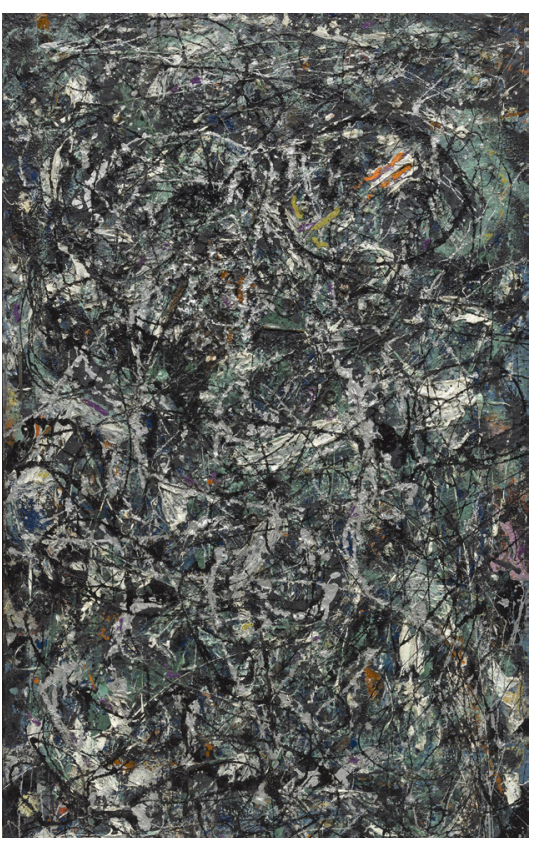

"[Pollock] the move he went on to make in the opening days of 1947, circling back somehow to the logic of the loft on Union Square, was to sweep the horizontal field of writing off the table that made it a surrogate for 'culture', and dump it -as so much trash- onto the floor of Squeiros's anticultural revolt. The floor, Pollock's work seemed to propose, in being below culture, was out of the axis of the body, and thus also below form. [...] This heterogeneity of trash which Pollock dumped onto the painting in the course of its execution testifies not merely to 'the internal meaning' of the work's horizontality but also to the 'bassesse' of this condition" [Bois, Krauss 1997, p. 95].

The images of the 'dripping' tell us about clues which are reflected in the theme of the forest; if darkness undermines the recognition of the various parts, making them unrecognisable (yet not invisible), Pollock's technique puts them in evidence through colours and depths. The reduction of entropic movements in the architectural palimpsest, based upon Dante's early maps (Dante the 'inventor' of 'dripping') which Pollock later represented, finds fertile ground in the operations related to Libeskind's encounter: a space, "a document of the unpredictable and an acknowledgment of the uncertain. In this, it reflects the nature of architecture itself. The spirit of architecture wanders where it will" [Libeskind 200 I, p. 17]. The project entitled Micromegas: The Architecture of Endspace ( 1979) (fig. 3) originated through a series of eleven pencil drawings on which a later set of prints is based. "Architectural drawings [writes Libeskind] have in modern times assumed the identity of signs; they 
Fig. 3. Daniel Libeskind (1946-): Micromega. Temporal Sections, 1979 New York Museum of Modern Art (MoMA). Silkscreen $361 / 8^{\prime}(66 \times 91.8 \mathrm{~cm})$ ( Robert K. and Barbara J. Straus Family Foundation, Inc. 271.1999 () 2021. Digital image,The

Museum of Modern Art New York/Scala, Firenze.

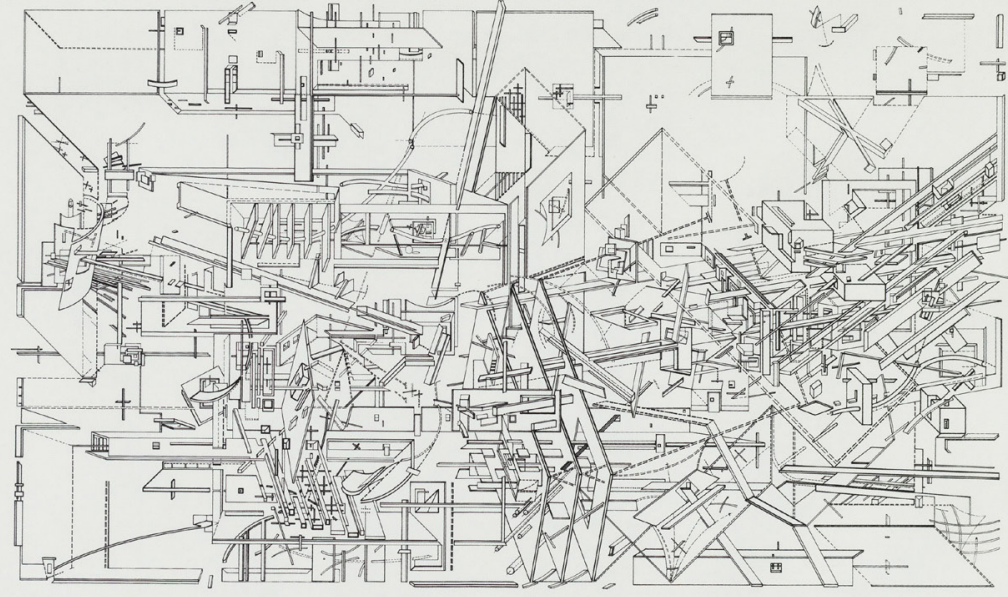

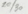

have become the fixed and silent accomplices in the overwhelming endeavor of building and construction [...] they have appeared as either self-effacing materials or as pure formulations cut off from every external reference" [Libeskind 200 I, p. 84].

The tools provided by Libeskind, through the drawings, ascribe to the forest the role of a device equipped with lines of tension which turn Libeskind's Micromegas into concrete interpretative fields, in which the action expressed by Agamben [2006] finds a representable placement and in which it is possible to recognise a reading and restitution of a space that addresses the formless. Micromegas does not impose conditions on the surroundings but rather enters into the wilderness, reflecting on a method that bears on the "wild" representation of the architectural project and the conditions of the space. The drawings subvert the classic axiom developed for a theory of order [Bertagna $20 \mathrm{l} \mathrm{I}$ ], building a formal system "as riddles in the form of unknown instruments for which usage is yet to be found [...] an instrument capable of revealing at a stroke new areas of the 'real'" [Libeskind 200 I, p. 84]. The forest-wilderness finds space in this new unknown, or forgotten, reality, in which it "is the trace that, cutting even as it marks, is the engine of heterogeneity, the instigator of différance" [Bois, Krauss 1997, p. I5 I]. The various levels of the wilderness can therefore be transversely assumed as extensions of a reality, both imaginary and concrete, which reveals "a structure whose manifestation is only mediated by symbolism" [Libeskind 200 I, p. 84]. "Here, therefore, it is not a question of a constituted difference but, prior to any determination of content, of the pure movement that produces the difference. "The (pure) trace is the dif-ference". It does not depend on any perceptible fullness, either audible or visible, phonic or graphic. It is, on the contrary, its concurrence" [Derrida 1969, p. 70].

The mise-en-scène in a context other than that where the wilderness is usually located shows -in Libeskind's operations, but not exclusively- the absence of control, but also, and especially, the non-existence or anticipation of definitive conditions, "an exchange between abstract ciphers exhausted in their own objectivity and hardened in fixed signs; and concrete contingencies responsive to the permanent solicitations of a spontaneous appeal" [Libeskind 200 I, p. 87]. The elements which compose the Little Universe are determined and outlined from the survey of the terrain, transposing the representation of traces and movements into operations "whose nucleus lies is the conflict between voluntary and involuntary" [Libeskind 200 I, p. 87] which, however, does not always concur with the dichotomy between order and disorder. 
Fig. 4. Junya Ishigami, Forest Kindergarten, 2018, (Ishigami, Junya, Freeing Architecture, LIXIL Publishing - Fondation Cartier pour l'art contemporain, Tokyo Panis 2018, pp. 146-147) (c) Junya Ishigami.

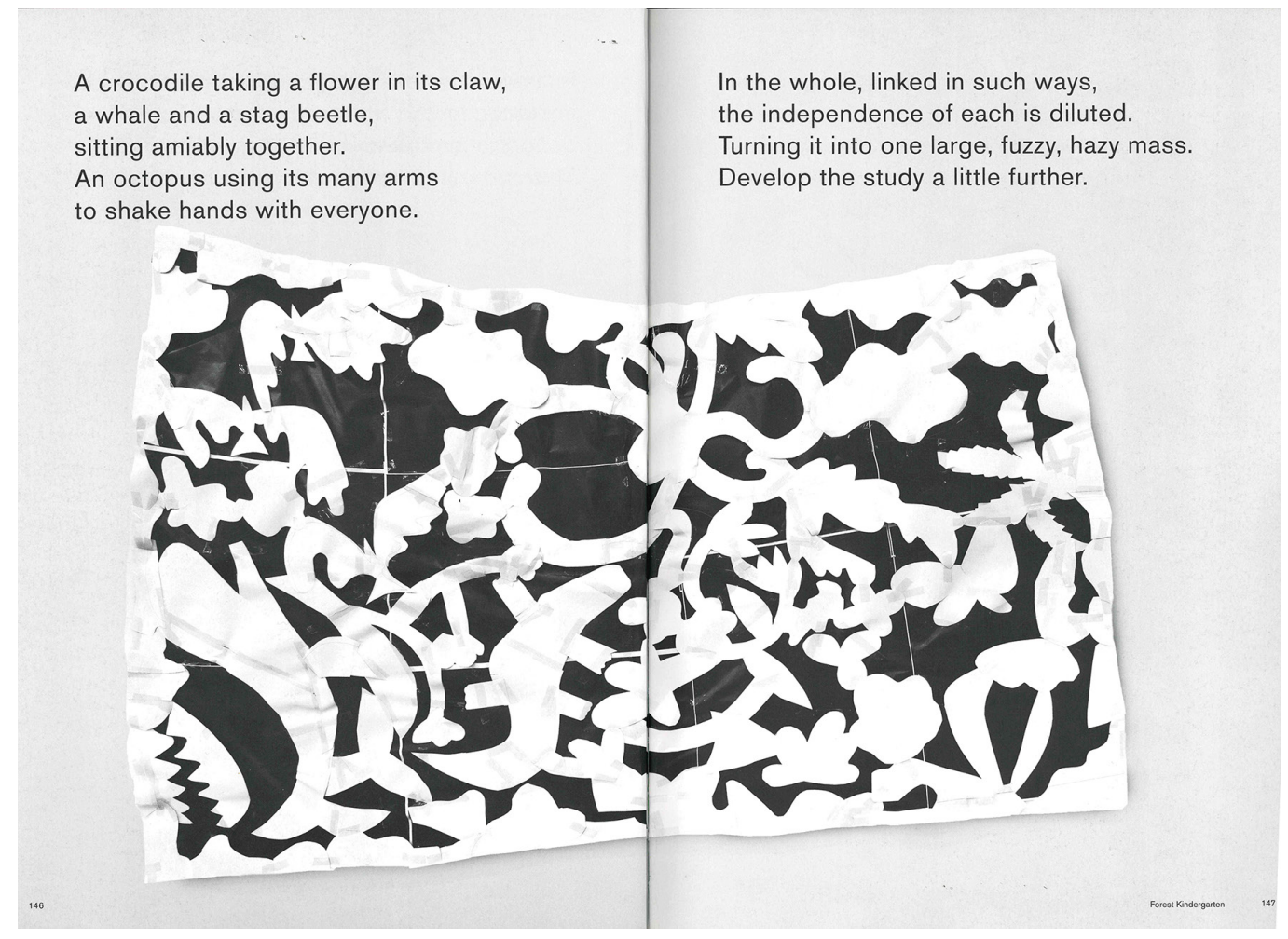

The drawings for Ishagami's Forest Kindergarten (2018) (fig. 4), further developing the theory, transpose traces of a destiny which Bataille had anticipated in his discussion of the term 'primitivism', and that in the drafts for the nursery school in Shandong, China, are presented as possible trails into the wilderness. The children walk along the spaces of an almost enchanted forest, produce maps and generate a dense network of signs which are added to those of the plants and animals, both living and architecturally reproduced. Abstraction and concreteness, in the same way as imagination and reality, guide the pathways without coercing interactions, thus allowing large animals to determine spaces and encouraging movements and 'drippings'. Ishigami operates in a world where "subjectivity and objectivity, immanence and transcendence, concrete and abstract" diverge [Ishigami 2018, p. 145], thus producing a sequence of maps that intersect the networks of children's pathways with those of the adults, ultimately mixing the pathways in a double circuit, vertical and horizontal, within a large, blurry and nebulous mass. "Adult-scale, child scale, interior, exterior, play equipment, landscape, plants, structures, brightness, darkness, quiet, noise, architecture extends amid all kinds of things merging into each other. [...] Ponder them at length in different ways, envisioning spaces within the lines. Like finding clearings in the jungle" [lshigami 2018, pp. 157-161].

\section{Afterword}

"Plants coincide with the forms they invent: for them, all forms are variations of being, and not of doing or acting. To create a form means to traverse it, to go through it with one's entire being, in the same way that one traverses the ages or the stages of existence.To the abstraction of creation and technique - which are capable of transforming forms only on the condition of excluding the artist and the producer from the process of transformation- the plant opposes the immediacy of metamorphosis: to generate always means being transformed" [Coccia 2019, p. 30].

Following a term which appears as number 7 in Bataille's Dictionnaire Critique, the report revisits the forest and the wilderness, proposing a condition, both present and future, in which 
there will increasingly be more space to traverse that has turned wild. Ishigami's images (fig. 5) follow a possible genealogy that had been anticipated by Libeskind, in which the transformation identified by Coccia expresses the modifications to the entropic sense of Dante's 'dripped' words according to Mandelstam, and finally to Pollock's 'dripping' technique, thus proposing methods of interpretation for an formless system in which the forest finds its place." Once again this duality (like that of realism-formalism) appears as an unsurpassable condition pointing to a dynamic ground, which testifies to an experience that receives only as much as it is capable of giving, draws only that which allows itself to be drawn into" [Libeskind 200 I, p. 87].

The dynamic nature of the wild terrain, which crosses numerous trails without any established order, therefore proposes a revision of the disciplinary notions in the field of architecture, identifying new forms of usage and of 'crossings' where the project-related developments discussed represent the diagram of "a non-exact figure which offers a general outline, set to narrate the forms and relationships between the parts, a form which is neither precise nor definitive, which can undergo modifications, yet reveals the results of a process and the variations that characterise it" [Marini 2010, p. 90]. This figure, according to the theory we have followed, is that of the imago sylvae, of the 'formless' in which the wilderness is anchored, thereby introducing operative scenarios that can be represented through maps, revealing the structures of a possible crossing by way of the project.

These drawings anticipate an image of the forest that does not only concern the plant or the animal (fig. 6) realms but also refers to the fabric of those sections of cities that have lost the features of control and order. Maps become the speculative instruments for interpreting an ambiguous system that can be traversed through lines of incursion; in other words an apparatus of strategies which is useful in augmenting the forms of coexistence, thus establishing a new and possible 'alliance' between the biological (forest) and the artefact (project).

Fig. 5. Junya Ishigami, Forest Kindergarten, 2018, (Ishigami, Junya, Freeing Archigami, Junya, Freeing Arch tecture, LIXIL Publishing Fondation Cartier pour lart contemporain, Tokyo Paris 2018, pp. |60-|6| C) Junya Ishigami.

Fig. 6. Gaston Phoebus, Livre de chasse, (detail) 19 $\times 15.3 \mathrm{~cm}, 1405-1410$ RCIN 912431, Ms. fr. 616 (C) Paris, Bibliothèque Nationale de France.
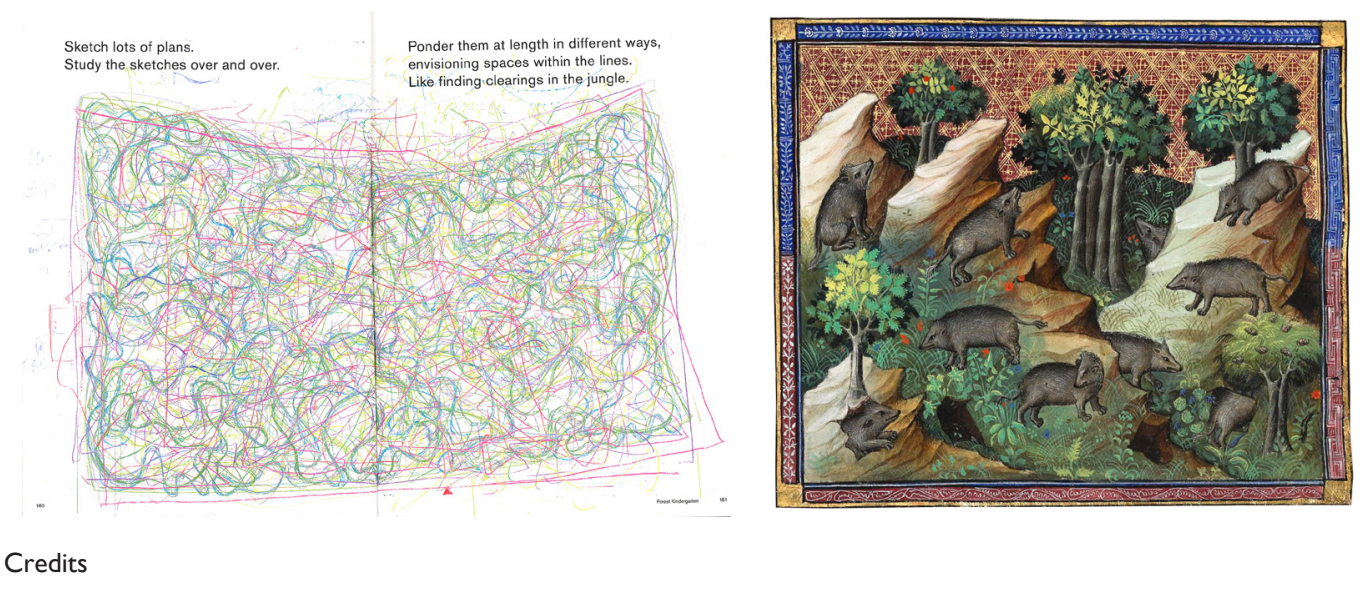

Some of the results presented here are the outcome of an ongoing research undertaken at the IUAV University of Venice as part of the PRIN (Research Project of National Relevance) entitled SYLVA - Rethink the sylvan.Towards a new alliance between biology and artificiality, nature and society, wilderness and humanity, IUAV University of Venice Research Unit (scientific supervisor: Professor Sara Marini).

\section{Notes}

[I] "The flexibility of plants' bodies is incomparable: "phenotypic plasticity" is the technical term used to describe this ability, They reduce their size, thicken, thin, coil, curve, climb, crawl, change the shape of their body, interrupt their own growth, do whatever is necessary for their balance with the environment to be as stable as possible. [...] A sort of paradox for living organisms that we perceive as fixed and sedentary but which, on the contrary, are able to cross barriers and colonise distant and inhospitable territories, moved by the irresistible urge of life to expand its presence" [Mancuso 20 19, pp. I08-I I 7].

[2] In this sense Mediaeval religious images, while referring to the 'natural' do not find a correspondence with the universe of forests; the patristic themes which emerge are placed within a diagram that has no escape routes and where the iconography results in finite projects, to be observed, in which the forest is presented only in a symbolical manner, and where "an example is found in Giotto's landscapes, true and proper architectures in which the forests are represented by way of a few sylised saplings" [Paci 2002, p. 32]

[3] "in Dante there is no single form, but rather a plurality. These forms drip through a process of pressing one over the other" [Rizzi 2016, p. 249]. 
[4] "Full fathom five thy father lies;/ Of his bones are coral made;/ Those are pearls that were his eyes:/ Nothing of him that doth fade/ But doth suffer a sea-change/ Into something rich and strange/ Sea-nymphs hourly ring his knell/ Hark! Now I hear them - Ding-dong, bell" [Shakespeare, The Tempest, Act. I, Sc. II, ca. I6 I0- I I].

\section{References}

Agamben G. (2006). Che cos'è un dispositivo?. Milano: Nottetempo.

Agnoletto M. (20 I 8). Storia del bosco. Il paesaggio forestale italiano. Bari: Laterza.

Bataille G. (1930). Les écarts de la nature. In Documents, n. 2, pp. 79-83.

Bataille G. (1974). Documents. Bari: Dedalo.

Bertagna A. (20I I ). I/ controllo dell'indeterminato: Potëmkin villages e altri nonluoghi. Macerata: Quodlibet.

Bois Y.-A., Krauss R. (1997). Formless: A User's Guide. New York: Zone Books.

Cacciari M. (1984). Un ordine che esclude la legge. In Casabella, n. 498-499, pp. I4, I5.

Cixous H. (1976). The Laugh of Medusa (translated by K. Cohen and P. Cohen). In Signs, vol. I, n. 4, pp. 875-893.

Coccia E. (2019). La vita delle piante. Metafisica delle mescolanze. Bologna: il Mulino.

Derrida J. (1969). Della grammatologia. Milano: Jaca Books.

Gentili D., Giardini, F. (2020). Selva e stato di natura: variazioni cinestesiche per il contemporaneo/ Sylva and State of Nature: Kinesthetic Variations for the Contemporary. In Vesper. Rivista di architettura, arti e teoria, n. 3, pp. 76-95.

Hillman J. (1977). Saggio su Pan (trad. it. A. Giuliani). Milano: Adelphi. [Prima ed. An Essay on Pan, in Pan and the Nightmare (con W. H. Roscher), Spring Publications, New York-Zürich 1972, pp. 3-65].

Hillman J. (2002). L'anima del mondo e il pensiero del cuore (trad. it. A. Bottini). Milano: Adelphi. [Prima ed. Anima Mundi:The Return of the Soul to the World. In Spring, 1982, pp. 7I-93].

Hillman J. (2016). Presenze animali (trad. it. di A. Serra e D.Verzoni). Milano: Adelphi. [Prima ed. The Animal Kingdom in the Human Dream. In Eranos Jahrbuch, n. 5I, 1982, pp. 279-334].

Ishigami J. (20I8). Freeing Architecture. Fondation Cartier pour l'art contemporain. Paris: LIXIL Publishing.

Libeskind D. ( 1997). Radix-Matrix. München-New York: Prestel.

Libeskind D. (200I). The Space of Encounter. London:Thames \& Hudson Ltd.

Mancuso S. (2019). La nazione delle piante. Bari-Roma: Laterza.

Mandel'štam O. (2003). Conversazioni su Dante (a cura di R. Faccani). Genova: II Melangolo.

Marini S. (20।0). Nuove Terre. Architetture e paesaggi dello scarto. Macerata: Quodlibet.

Marini S. (2020). Nella selva/ Wildness. In Vesper. Rivista di architettura, arti e teoria, n. 3, pp. I0- I7.

Marini S., Bertagna A. (20I I) (Eds.). The Landscape of Waste. Milano: Skira.

Morton T. (2016). Dark Ecology. For a Logic of Future Coexistence. New York: Columbia University Press.

Paci M. (2002). L'uomo e la foresta. Milano: Meltemi.

Rizzi R. (2016). Forma. In S. Marini, G. Corbellini (a cura di). Recycled Theory: Dizionario illustrato/ Illustrated Dictionary. Macerata: Quodlibet, pp. 248-249.

\section{Author}

Vincenzo Moschetti, Università IUAV di Venezia, vmoschetti@iuav.it

To cite this chapter. Moschetti Vincenzo (2021). Imago Sylvae. Strumenti di attraversamento e rappresentazione dello spazio selvatico/lmago Sylvae. Instruments for navigating and representing the wilderness. In Arena A., Arena M., Mediati D., Raffa P. (a cura di). Connettere. Un disegno per annodare e tessere Linguagri Distanze Tecnologie Atti del $42^{\circ}$ Convegno Internazionale dei Docenti delle Discipline della Rappresentazione/Connecting Drawing for weaving relationship. Languages Distances Technologies. Proceedings of the $42^{\text {th }}$ International Conference of Representation Disciplines Teachers. Milano: Franco Angeli, pp. 909-924. 